\title{
PENYUSUNAN PERJANJIAN KERJA ANTARA PEMAIN SEPAK BOLA PROFESIONAL DENGAN KLUB PERSIS SOLO
}

\author{
Muhammad Faizal T.A. \\ E-mail: muhmdfzal@gmail.com \\ Mahasiswa Fakultas Hukum Universitas Sebelas Maret \\ Arief Suryono \\ E-mail: ariefsuryono@staff.uns.ac.id \\ Dosen Fakultas Hukum Universitas Sebelas Maret
}

\begin{abstract}
This article Aims to find out, describe, and analysis the cooperation agreement process between football players with Persis Solo football club. This research uses the normative legal approach. The research was prescriptive or applied. The research approach used by the authors is by the legislation approach. The legal material used by the authors is the primary legal material and secondary legal material. The techniques of collecting legal materials authors using literature study techniques and technical analysis techniques using silogism methods. Process agreement between the club exactly with the player is a process of agreement made unilaterally (the club) by using the standard professional contract PSSI. The agreement has qualified the terms of the agreement set forth in article 1320 of the KUH Perdata. The agreement also qualifies for a specific employment contract, in which the agreement must be made in writing.
\end{abstract}

Keywords: Agreements; Employment Contracts; Football Players; Football Clubs

\begin{abstract}
Abstrak
Artikel ini bertujuan untuk mengetahui, mendeskripsikan, dan menganalisa proses perjanjian kerjasama antara atlet pemain sepakbola dengan Klub Persis Solo. Penelitian ini menggunakan penelitian hukum normatif. Penelitian ini bersifat preskriptif atau terapan. Pendekatan penelitian yang digunakan oleh penulis adalah dengan pendekatan Perundang-undangan. Bahan hukum yang digunakan penulis adalah bahan hukum primer dan bahan hukum sekunder. Teknik pengumpulan bahan hukum penulis menggunakan teknik studi kepustakaan dan teknik analisis bahan hukum menggunakan metode silogisme. Proses perjanjian antara klub Persis dengan pemainnya merupakan proses perjanjian yang dibuat secara sepihak (klub) dengan menggunakan standar kontrak profesional PSSI. Perjanjian tersebut telah memenuhi syarat sahnya perjanjian yang diatur dalam Pasal 1320 KUHPerdata. Perjanjian tersebut juga telah memenuhi syarat perjanjian kerja waktu tertentu (PKWT), dimana perjanjian harus dibuat dengan cara tertulis.
\end{abstract}

Kata Kunci: Perjanjian; Perjanjian Kerja; Pemain Sepakbola; Klub Sepakbola

\section{A. Pendahuluan}

Sepak bola merupakan salah satu cabang olahraga yang paling populer dan banyak diminati oleh masyarakat dunia, tak terkecuali masyarakat di Indonesia. Survei yang dilakukan oleh Federation Internationale De Football Association (FIFA) pada tahun 2001 menyatakan bahwa sepak bola adalah olahraga yang paling populer di dunia (Pranata \& Supatmi. 41: 2014).

Pada saat ini sepak bola bukan lagi sebatas cabang olahraga yang paling banyak diminati masyarakat, namun sepak bola kini sudah berkembang menjadi sebuah peluang kerja. Ada beberapa pemain sepak bola yang telah memanfaatkan olahraga sepakbola sebagai mata pencaharian (Erma Novianti. 1: 2014). Klub tidak hanya bersaing dalam memperoleh target untuk menjuarai kompetisi atau turnamen saja, akan tetapi sebuah Klub juga mempunyai daya saing dalam jual beli pemain profesional dan juga memperoleh keuntungan sebesar-besarnya dalam kegiatan cabang olahraga ini. 
Dalam perjanjian kerja atau kontrak kerja antara pemain dengan klub sepak bola, pihak pemain dan pihak klub akan saling terikat satu sama lain sehingga menimbulkan hak dan kewajiban kepada masing-masing pihak. Perjanjian kerja ialah perjanjian antara seorang buruh dengan seorang majikan yang ditandai dengan ciri adanya suatu upah atau gaji tertentu yang diperjanjikan dan adanya suatu hubungan diperatas (dienstverhoeding), dimana pihak majikan berhak memberikan perintah-perintah yang harus ditaati oleh pihak lain (Subekti, 1995: 58). Dalam hal ini pemain sepak bola disebut sebagai pekerja, dan pihak Klub disebut sebagai si pemberi kerja.

Pemain akan dikontrak oleh klub dengan adanya suatu kesepakatan yang telah disetujui atau diterima oleh kedua belah pihak. Dalam suatu perjanjian atau kontrak kerja maka terjadilah suatu perikatan. Suatu perikatan tidak akan ada artinya kalau prestasi tidak dapat diwujudkan. Untuk mewujudkan prestasi itu perlu ada tanggung jawab. Jadi, di samping kewajiban berprestasi perlu juga diimbangi dengan tanggung jawab. Jika tanggung jawab ini tidak ada, kewajiban berprestasi tidak ada arti menurut hukum. Dalam setiap perjanjian, kewajiban para pihak selalu disertai tanggung jawab menurut hukum. Inilah hakekat perjanjian yang diakui dan diberi akibat hukum dalam kehidupan masyarakat (Abdulkadir Muhammad. 13: 2000).

Syarat sepakat yang mengikatkan diri di dalam perjanjian olahraga merupakan kesepakatan perjanjian kontrak kerja antara pemilik klub dengan pemain, dengan tanggung jawab klub wajib memfasilitasi para pemainnya selama masa kontrak dan juga membayar gaji secara tepat waktu kepada pemain sesuai dengan draf perjanjian dan tanggung jawab pemain sepak bola yaitu dengan memberikan kemampuan keterampilan bermain bola secara profesional kepada Klub agar mencapai target, visi dan misi dari Klub. Setelah melakukan perjanjian/kontrak kerja, maka para pihak mempunyai kewajiban disertai tanggung jawab terhadap isi dari perjanjian yang telah disepakati. Namun dalam praktek perjanjian kontrak kerja biasanya timbul permasalahan seperti tidak terpenuhinya prestasi oleh salah satu pihak dalam perjanjian. Dan hal ini menimbulkan permasalahan hukum bagi para pihak yang mengadakan perjanjian tersebut (Erwan Priambada, 2007: 74). Seperti contoh pihak Klub tidak melaksanakan kewajibannya dengan tidak memberikan upah kepada pemainnya seperti pada kasus yang dialami oleh Diego Mendieta pemain dari Klub Persis Solo pada musim 2011/2012 yang meregang nyawa akibat tidak bisa membayar biaya pengobatan rumah sakit karena gaji yang tidak dibayarkan oleh Klub tersebut.

Penyusunan perjanjian kerja antara pemain sepak bola dengan Klub di Indonesia sendiri merupakan perjanjian baku yang dibuat oleh PSSI selaku Federasi sepak bola di Indonesia yang kemudian ditetapkan dalam standar kontrak PSSI. Suatu perjanjian hendaknya dibuat oleh kedua belah pihak, namun disini suatu draf perjanjian dibuat oleh Federasi yang kemudian diambil oleh klub dan nantinya pemain selaku pekerja hanya memiliki pilihan untuk melakukan persetujuan, apakah pemain akan menyetujui kontrak tersebut atau menolaknya. Terkait dengan klausulklausul perjanjian kerja tersebut merupakan suatu hal yang baku bagi pemain karena pemain tidak dapat mengubah isi/klausul perjanjian tersebut sama seperti dalam perjanjian kerja antara Klub Persis Solo dengan pemainnya. Suatu kontrak yang disusun oleh salah satu pihak saja tentunya cenderung tidak seimbang sehingga dalam perjanjian kerja antara pemain sepak bola dengan Klubnya lebih menguntungkan pihak Klub selaku pemberi kerja. Berdasarkan uraian di atas artikel ini akan membahas tentang bagaimana penyusunan dan analisis terhadap perjanjian kerja antara pemain sepak bola profesional dengan klub Persis Solo.

\section{B. Metode Penelitian}

Penelitian hukum ini menggunakan penelitian hukum normatif. Penelitian ini bersifat preskriptif atau terapan. Pendekatan penelitian yang digunakan oleh penulis adalah dengan pendekatan Perundang-undangan. Bahan hukum yang digunakan penulis adalah bahan hukum primer dan bahan hukum sekunder. Teknik pengumpulan bahan hukum penulis menggunakan teknik studi kepustakaan dan teknik analisis bahan hukum menggunakan metode silogisme. 


\section{Hasil Penelitian dan Pembahasan}

Proses penyusunan perjanjian kerja antara pemain sepak bola profesional dengan klub Persis Solo yakni dengan melakukan prakontrak, kontrak dan paskakontrak.

a. Prakontrak

Prakontrak antara klub Persis dengan pemain meliputi tiga hal di antaranya:

1) Negosiasi

Proses negosiasi klub Persis Solo dengan Pemainnya dilakukan secara non formal dan formal, dalam sektor non Formal dilakukan dengan:

a) Lobby pihak klub meyakinkan pemain (bagi pemain yang bebas transfer yang artinya pemain yang tidak terikat kontrak dengan klub lain),

b) Lobby pihak klub membuat kesepakatan lepas untuk membicarakan kesepakatan masa depan pemain sebelum perpindahan pemain dari klub lama (bagi pemain yang masih terikat kontrak dengan klub lain), dan bagi pemain yang berstatus bebas kontrak maka hanya untuk membicarakan praperikatan antara kedua belah pihak.

Negosiasi sektor formal yaitu:

(1) Negosiasi sektor formal dilakukan pihak klub Persis Solo dengan klub lain (klub pemilik lama) yang memiliki pemain yang akan dibeli (bagi pemain yang masih terikat kontrak dengan klub/klub lama).

(2) Pihak klub Persis Solo melakukan negosiasi dengan pemilik pemain (klub lama) membicarakan kesediaan klub lama melepaskan pemain (yang akan dibeli dalam bursa transfer).

(3) Pihak klub Persis Solo melakukan penawaran terhadap klub lain (klub pemilik lama) supaya tercipta transaksi sebelum adanya kontrak, penawaran terhadap harga perpindahan dari klub lama menuju klub baru Persis, jika adanya kesepakatan selanjutnya pihak klub Persis mendaftarkan pemain pada Komite Eksekutif PSSI untuk berada dalam bursa transfer pemain (klub lama sudah sepakat bahwa pemain didaftarkan dalam bursa transfer).

Prosesi kontrak atau pun jual beli pemain ini terjadi dalam bursa transfer pemain yang diatur dalam masa tenggang waktu tertentu. Di Indonesia sendiri tata cara transfer pemain diatur dalam statuta Organisasi Persatuan Sepakbola Seluruh Indonesia (PSSI) Tahun 2018 yang tertuang dalam:

Pasal 7 yang mengatur tentang Pemain

a) Status pemain dan ketentuan mengenai transfer pemain diatur oleh Komite Eksekutif sesuai dengan Peraturan FIFA Regulations on the Status and Transfer of Players yang berlaku.

b) Pemain harus didaftarkan sesuai dengan peraturan yang dikeluarkan oleh PSSI.

c) Dalam mengatur persepakbolaan nasional, PSSI mengakui pemain amatir dan profesional (non-amatir).

d) Pemain asing diizinkan untuk bermain dalam kompetisi Sepak Bola profesional yang diselenggarakan oleh Liga di bawah naungan PSSI untuk mengembangkan kualitas persepakbolaan nasional dan untuk memacu terciptanya Tim Nasional yang berprestasi.

Maka dari itu tolak ukur klub Persis Solo dalam melakukan negosiasi dengan para calon pemain/klub pemilik calon pemain adalah dengan mematuhi aturan dari Statuta PSSI tersebut, serta negosiasi dilakukan untuk kesepakatan nilai kontrak pemain. 
2) Memorandum of Understanding (MoU)

Setelah adanya negosiasi pemain baik formal (bagi pemain yang masih terikat kontrak dengan Klub lain) maupun dengan Non formal (bagi pemain yang bebas dari kontrak tim lain atau dalam istilah sepak bola adalah free transfer), maka klub Persis melakukan Memorandum of understanding (MoU) atau tanda kesepakatan pascanegosiasi yang memastikan pemain bergabung dengan dengan klub Persis Solo, serta membahas tentang kesepakatan berapa gaji pemain yang akan dibayar ketika nanti membela klub Persis, serta juga berapa nilai transfer pemain kepada klub (bagi pemain yang masih berstatus pemain milik klub lain).

Dalam tahap pelaksanaan MoU ini merupakan proses jembatan dalam penyusunan kontrak kerja yang akan dilakukan klub Persis dengan para pemain. Berapa nilai transfer, gaji, tunjangan, dan hal-hal kontrapresiasi kedua belah pihak. Setelah adanya MoU, maka ini merupakan tahap lepasnya pemain dengan klub lama (bagi pemain yang masih memiliki status kontrak dengan klub lama).

Selanjutnya mengenai hak dan kewajiban dan akibat dalam kontraprestasi tersebut diatur dalam kontrak kerja klub Persis Solo dengan pemainnya.

3) Studi kelayakan

Studi kelayakan mengenai kontrak dalam persepakbolaan meliputi:

a) Kelayakan dari klub Persis sendiri sebagai klub profesional yang sudah dijamin oleh PSSI dan Liga.

b) Selanjutnya kelayakan dari pemain itu sendiri yang diatur di dalam Statuta PSSI pasal 7 , yang menggambarkan kualifikasi pemain yaitu Pemain harus didaftarkan sesuai dengan peraturan yang dikeluarkan PSSI, dan dikategorikan sebagi pemain amatir maupun profesional, serta dokumen-dokumen legal yang bersangkutan dengan pemain.

c) Kelayakan permainan serta kesehatan para pemain yang meliputi:

(1) Kesehatan tubuh dalam maupun luar,

(2) Tes bebas narkoba, dan

(3) Doping seperti tercantum dalam perjanjian kontrak kerja Persis pasal Pasal 14 tentang Doping.

b. Perjanjian (Tahap Penyusunan Perjanjian)

Setelah proses prakontrak yang sudah dijelaskan di atas, maka tahap selanjutnya adalah tahap penyusunan kontrak. Dalam proses pembuatan draf kontrak kerja diperlukan adanya ketelitian dan kejelian dalam menangkap keinginan para pihak, memahami aspek hukum, menguasai bahasa perjanjian yang tepat, singkat, jelas dan sistematis. Berdasarkan wawancara penulis dengan Bona Syarifudin selaku manajer Persis Solo, Proses dalam penyusunan perjanjian antara Klub Persis dengan pemainnya meliputi 3 tahapan, yakni membuat draf perjanjian, Koreksi draf perjanjian oleh masing-masing pihak, dan yang terakhir adalah Penandatangan kontrak. Penjabarannya adalah sebagai berikut:

1) Membuat draf perjanjian

Pembuatan draf perjanjian dibuat oleh Klub Persis Solo dengan menggunakan format Standar Kontrak Profesional yang disediakan oleh PSSI, dalam pembuatan draf perjanjian memuat:

a) Judul Kontrak (Heading/ Contract Title)

Kontrak Persis dengan pemainnya berjudul Perjanjian Kerja Pemain Sepak Bola Profesional dan kepala kontrak diisi dengan identitas Klub Persis Solo sebagai pihak yang mengeluarkan perjanjian, yang selanjutnya disebut dengan Perjanjian Kerja Pemain Profesional Persis Solo. 
b) Tempat dan Tanggal Penandatanganan

Tanggal penandatanganan diisi pada saat para pihak menandatangani perjanjian pada saat itu juga, seperti pada lampiran draf perjanjian Klub Persis dengan Absor Fauzi yang ditandatangani pada tanggal Lima April Dua Ribu Delapan Belas (05-042018) di tempat sekretariat Persis Solo yang beralamat di Jl. Adi Sutjipto No.79 Kel. Jajar, Kec. Laweyan, Surakarta.

c) Komparasi (Perbandingan)

Komparasi kontrak kerja Persis dengan pemainnya memuat identifikasi para pihak yang terlibat dan mengikatkan diri di dalam kontrak perjanjian kerja, dalam hal ini pihak Persis Solo sendiri dengan Pemain maupun calon pemain, adalah sebagai berikut:

1. Nama

Tanggal Lahir

No. KTP

Alamat

\section{ABSOR FAUZI}

Bandung, 11 Agustus 1987

: 3204371108870003

KP. Cingcin Kolot RT.002, RW.017,

Cingcin, Kec. Soreang, Kabupaten Bandung, Jawa Barat

dari dan oleh karenanya bertindak untuk dan atas nama diri sendiri (selanjutnya disebut sebagai "Pemain").

2. Klub Sepakbola PERSIS SOLO

adalah klub sepak bola yang termasuk anggota Persatuan Sepakbola Seluruh Indonesia (PSSI), yang berkedudukan di Jl. Adi Sutjipto No.79 Kel. Jajar, Kec. Laweyan, Surakarta yang dalam hal ini diwakili oleh SIGID AGUS HERYANTO dalam kapasitasnya sebagai CEO KLUB SEPAKBOLA PERSIS SOLO

dari dan oleh karenanya sah bertindak untuk dan atas nama Klub Sepakbola PERSIS SOLO (selanjutnya disebut sebagai "Klub").

Yang dapat menjadi pihak dalam kontrak adalah subjek hukum perdata dan pemain sebagai perorangan. Baik dari Persis Solo dengan para pemain telah memenuhi syarat kecakapan bertindak. Saat ini Persis Solo merupakan badan hukum yang dikelola oleh PT Persis Solo Saestu (PT PSS) maka suatu badan hukum sebagai subjek hukum harus memenuhi syarat tambahan, yaitu bahwa dia juga memiliki kewenangan bertindak, dan Persis Solo telah memenuhinya karena merupakan anggota resmi PSSI dan telah menjadi klub profesional di bawah naungan PSSI sebagai perserta Liga 2 Indonesia.

d) Recitals (Pertimbangan-Perimbangan Umum Kontrak)

Berisikan kondisi umum dari para pihak yang akan membuat suatu kontrak, berisikan maksud dan tujuan membuat perjanjian. Dalam perjanjian kerja pemain sepak bola profesional milik Persis pertimbangan-pertimbangan umum kontrak, adalah sebagai berikut:

Pemain dan Klub selanjutnya secara bersama-sama disebut sebagai "Para Pihak".

Para Pihak dengan ini terlebih dahulu menerangkan hal-hal sebagai berikut:

1) Bahwa Klub adalah klub sepakbola PERSIS SOLO anggota Persatuan Sepakbola Seluruh Indonesia (PSSI) yang mengikuti Kompetisi LIGA 2 Musim 2018.

2) Bahwa Pemain adalah individu yang memiliki keahlian di bidang olahraga sepakbola yang telah memenuhi persyaratan sebagaimana ditetapkan oleh PSSI dan PT Liga Indonesia Baru (LIB) untuk bermain di klub sepakbola profesional di Indonesia dengan ikatan kerja dalam waktu tertentu dan pada saat Perjanjian ini ditandatangani tidak sedang terikat ikatan kerja sebagai pemain sepakbola dengan pihak manapun. 
3) Bahwa dalam rangkat keikutsertaan Klub di kompetisi dan turnamen baik nasional maupun internasional yang diselenggarakan oleh PSSI, LIB, Asean Football Federation (AFF), Asian Football Confedaration (AFC) dan Federation Internationale de Football Association (FIFA) maka Klub bermaksud untuk melakukan ikatan kerja dengan Pemain.

4) Bahwa PEMAIN dengan ini sepakat untuk bermain di KLUB sebagai PEMAIN profesional di seluruh kompetisi dan turnamen yang diikuti oleh KLUB baik Kompetisi LIGA 2 Musim 2018, Kompetisi Lokal lainnya maupun Kompetisi Internasional.

Dalam kontrak tersebut jelas maksud kedua belah pihak masing-masing untuk mengikatkan diri, baik pihak klub maupun pemain dan maksud keduanya untuk saling melakukan prestasi. Maka, berdasarkan hal-hal tersebut di atas, Para Pihak telah saling sepakat untuk mengadakan ikatan kerja.

e) Isi Kontrak

Isi perjanjian kerja pemain sepak bola profesional Persis memuat pasal-pasal yang secara sederhana dapat digambarkan bahwa Pasal adalah bagian dari suatu kontrak yang terdiri dari kalimat atau sejumlah kalimat yang menggambarkan kondisi dan informasi tentang apa yang disepakati, baik secara tersurat maupun tersirat. Maka kontrak tersebut berisi:

Pasal 1 tentang Definisi,

Pasal 2 tentang Ruang Lingkup Perjanjian,

Pasal 3 tentang Syarat-Syarat Perjanjian,

Pasal 4 tentang Jangka Waktu Perjanjian

Pasal 5 tentang Nilai Perjanjian dan Cara Pembayaran

Pasal 6 tentang Bonus Kemenangan

Pasal 7 tentang Remunerasi Biaya Pengobatan

Pasal 8 tentang Kewajiban, Hak dan Larangan-Larangan bagi Pemain

Pasal 9 tentang Kewajiban, Hak dan Larangan-Larangan bagi Klub

Pasal 10 tentang Hak Penampilan

Pasal 11 tentang Evaluasi

Pasal 12 tentang Peminjaman

Pasal 13 tentang Disiplin

Pasal 14 tentang Doping

Pasal 15 tentang Kebenaran Informasi

Pasal 16 tentang Pengakhiran Perjanjian

Pasal 17 tentang Penyelesaian Perselisihan

Pasal 18 tentang Kerahasiaan

Pasal 19 tentang Regulasi Sepakbola

Pasal 20 tentang Pemberitahuan dan Korespodensi

Pasal 21 tentang Penutup

Jadi dalam hal ini setelah dikaji oleh penulis mengenai penyusunan draf kontrak perjanjian antara Klub Persis Solo dengan pemainnya, perjanjian kerja antara Klub Persis Solo dengan pemainnya merupakan perjanjian baku yang dibuat oleh PSSI selau Federasi sepak bola di Indonesia yang ditetapkan pada standar kontrak PSSI. Proses penyusunan perjanjian kerja antara Klub Persis Solo dengan pemainnya yakni dilakukan dengan tahap prakontrak, kontrak dan pascakontrak. Perjanjian kerja 
tersebut merupakan perjanjian baku yang dibuat oleh PSSI selaku Federasi sepak bola Indonesia. Semua isi/klausul yang terdapat dalam draf perjanjian Klub Persis Solo dengan pemainnya harus sesuai dengan standar kontrak PSSI yang dituangkan dalam statutanya. Perjanjian tersebut juga sudah sesuai dengan aturan kontrak PSSI, namun dalam pembuatan perjanjian kerjanya tidak menjelaskan isi dari perjanjian secara jelas dan terdapat kecacatan dalam salah satu klausul kontrak, yakni Pasal 1 tentang definisi dan Pasal 17 tentang Penyelesaian Perselisihan. Terkait Pasal 17 tentang Penyelesaian Perselisihan dimana tidak dapat dijalankan nantinya karena badan penyelesaian perselisihan yang digunakan dan diatur dalam pasal tersebut belum terbentuk di Indonesia. Pihak klub tetap mencantumkan pasal tersebut karena terdapat larangan terhadap pihak klub untuk mengganti dan menghapus tiap klausul dalam perjanjian oleh PSSI. Pihak Klub hanya diperbolehkan untuk menambahkan isi klausul kontrak, itupun juga harus melalui persetujuan yang diberikan oleh APPI selaku Asosiasi pemain sepak bola profesional. Hal ini tentunya sangat merugikan para pihak yang ada dalam perjanjian, teruma pihak pemain selaku pekerja. Perjanjian ini juga tidak sesuai dengan asas kebebasan berkontrak, dimana para pihak yang terlibat dalam perjanjian ini tidak bebas untuk mengatur isinya, dalam hal yang dimaksud di sini pihak klub dan pemain tidak dapat menambah/mengganti isi klausul kontrak yang sudah dibuat oleh PSSI.

\section{Simpulan}

Proses penyusunan perjanjian kerja mengacu pada aturan dari regulasi yang dibuat oleh PSSI selaku Federasi Sepak bola Nasional. Draf perjanjian tersebut sudah sesuai dengan Standar Kontrak Profesional PSSI karena dari bagan-bagan kontraknya tidak melenceng dari Standar Kontrak Profesional dari PSSI. Mengingat perjanjian ini harus sesuai dengan standar kontrak PSSI, maka pihak klub tidak diperbolehkan untuk menghapus isi klausul kontrak perjanjian, klub hanya diperbolehkan untuk menambahkan klausul kontrak itupun harus melalui persetujuan yang diberikan oleh APPI.

Jika mengacu pada KUHPerdata yang mana terdapat hukum yang mengatur tentang perjanjian, maka draf kontrak perjanjian tersebut telah memenuhi syarat sahnya perjanjian yang diatur Pasal 1320 KUHPerdata yakni adanya kesepakatan para pihak, kecakapan dalam melakukan perbuatan hukum, adanya objek perjanjian, dan klausa yang halal.

\section{E. Saran}

1. Saran kepada PSSI untuk segera membentuk Lembaga NDRC karena ini juga sudah berlaku dalam regulasi yang dibuat oleh FIFA selaku federasi sepak bola Internasional. NDRC merupakan Lembaga penyelesaian sengketa khusus untuk menangani sengketa di cabang olahraga sepak bola, terutama mengenai pemain dan perjanjian kerjanya dengan Klub sepak bola.

2. Saran kepada Klub Persis Solo untuk mencari upaya penyelesaian perselisihan dengan menggunakan Lembaga lain yang dinilai bisa digunakan dalam menyelesaikan perselisihan Klub dengan para pemainnya. Badan arbitrase khusus olahraga juga bisa digunakan untuk menyelesaikan permasalahan dalam olahraga sepak bola, yakni melalui BAORI (Badan Arbitrase Olahraga Indonesia) yang berfungsi untuk menyelesaikan sengketa keolahragaan di bidang olahraga.

3. Saran kepada pemain diharapkan untuk bisa memahami isi dari tiap klausul perjanjian, lalu apabila ditemukan permasalahan maka pemain sebaiknya bisa mengajukan keberatan/ melakukan perundingan kepada pihak Klub untuk bisa merevisi isi dari perjanjian supaya perjanjian benar-benar dapat mengakomodir kepentingan dan hak-hak para pihak dan tidak merugikan salah satu pihak. 


\section{Daftar Pustaka}

Abdulkadir Muhammad. 2000. Hukum Perdata Indonesia. Bandung: PT Citra Aditya Bakti.

Subekti. 2003. Pokok-Pokok Hukum Perdata. Jakarta: Intermasa.

Elvina Chandra Pranata \& Supatmi. 2014. "Analisis Kinerja Keuangan pada Klub Sepak Bola (Studi Kasus pada Arsenal, Tottenham Hotspur dan Everton)." Jurnal Ekonomi dan Bisnis. Volume XVII Nomor 2.

Erma Novianti. 2014. BONITA (Bonek Wanita) (Studi Deskriptif tentang Makna Bonek Wanita Sebagai Suporter Persebaya). Jurnal Komunitas, Volume 3 Nomor

Erwan Priambada. 2017. "Kajian Yuridis Penyelesaian Wanprestasi pada Kontrak Antara Pemain Sepak Bola Profesional dengan Klub Persiba Bantul”. Privat Law, Vol. V No.1. Universitas Sebelas Maret Surakarta

Statuta FIFA

Statuta PSSI 